\title{
Promega changes tack in battle over patent
}

\section{Jonathan Knight, San Francisco}

A company that sells an enzyme used in the polymerase chain reaction (PCR) is suing the corporation that holds a patent on it, alleging that researchers who use the enzyme almost every day are being overcharged.

Promega of Madison, Wisconsin, has filed a lawsuit against the Swiss pharmaceutical giant Hoffmann-La Roche, which holds a patent on the Taq enzyme. In the suit, which was filed on 13 November at a federal district court in Virginia, Promega alleges that government-funded researchers, who use the enzyme in PCR to amplify genetic material, are paying Roche too much.

Promega is claiming $\$ 1$ billion under a law that allows you to file a suit against anyone you think is swindling the US federal government. If successful, the company stands to collect up to $30 \%$ of any award. Roche says that the allegations are "without merit".

The case is being pursued under the 1863 False Claims Act, which protects the govern-

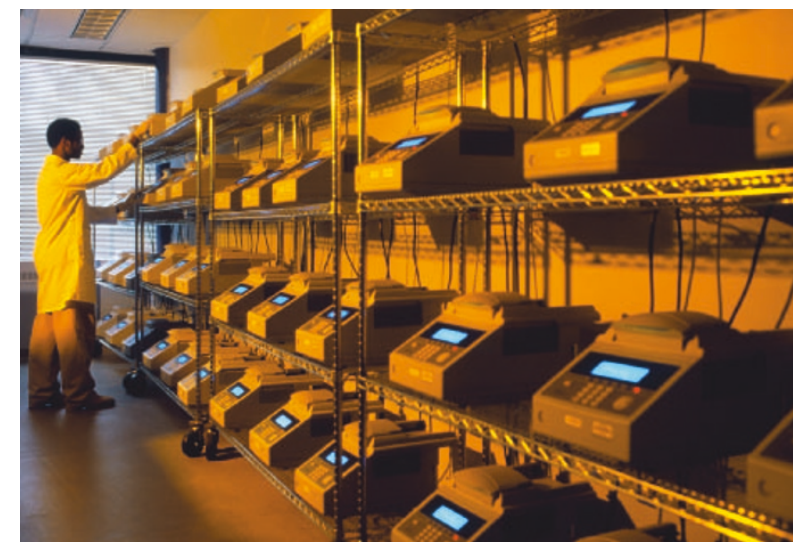

PCR is at the heart of gene-sequencing - and patent litigation.

ment against fraud by allowing citizens to sue on the government's behalf. A 1986 amendment allowed the litigant to claim treble damages and raised the maximum amount that the litigant may pocket from $25 \%$ to $30 \%$ of the total. Since then, the

\section{US draws up plans to tackle autism}

Emily Singer, Washington

The National Institutes of Health (NIH) is preparing a research plan for autism - and hopes to cut the condition's prevalence in the United States by a quarter by 2013.

The NIH autism 'roadmap', revealed on 19 November at a planning meeting of researchers and autism activists in Washington DC, will aim to identify the genetic, environmental and neurological factors behind the disorder. It represents the biomedical research agency's first concerted push to tackle the condition, which afflicts up to 1 in 200 people in the United States.

Requested by the Congress last year, the roadmap was drawn up by the Interagency Autism Coordinating Committee, a group of scientists, autism advocates and publichealth experts. It may form the basis of future budget requests from the National Institute of Mental Health (NIMH), which will lead its implementation.

By setting specific benchmarks for treating the disorder, the plan is something of a departure for the NIH, reflecting the results-oriented approach advocated by its director, Elias Zerhouni (see Nature 425, 438; 2003). The main scientific aspects of the roadmap include building a database of genes potentially linked to autism, and a series of clinical trials to determine the effectiveness of various early treatments for the condition. But the plan also sets what it calls a "high-risk" goal of reducing incidence of the disorder by $25 \%$ within ten years.
Researchers haven't tackled these problems before, partly because so little is understood about the mechanisms behind autism. There is currently no biological diagnosis for the disorder. "We have no genes, no circuits, no workable animal models, so we don't have the tools to develop new treatments," says NIMH director Thomas Insel. "It's a striking contrast to where we are with the rest of medicine. We are where we were eight years ago with Alzheimer's disease or 20 years ago with Huntington's."

At this point, NIH officials don't know how much money will be available to support the initiative. But some of the work will be done at eight autism research centres, established last year by the NIH, with a total budget of $\$ 65$ million over five years.

The NIH and the National Alliance for Autism Research, an advocacy group based in Princeton, New Jersey, are already supporting a $\$ 4.5$-million project to coordinate the search for autism-related genes. Now advocacy groups hope that the roadmap will form the basis of a larger, publicly supported investigation of the condition.

"It's gratifying to see the government addressing it at such a high level and with such high priority," says Lee Grossman, chairman of the Autism Society of America, an advocacy group based in Bethesda, Maryland. "It's what we've been asking for for decades." number of suits under the act has soared, and the US Treasury has recovered more than $\$ 10$ billion.

"It certainly is an innovative tactic," says Greg Aharonian, a technology patent consultant based in San Francisco. Of half-a-dozen intellectual-property lawyers contacted by Nature, none had heard of the act being invoked in a patent dispute.

Roche and Promega have been wrangling over Taq since 1992, when Roche sued Promega for violating its patent on the enzyme, which is isolated from the bacterium Thermus aquaticus that lives in hot springs. Roche obtained the patent in 1991 from Cetus, a nowdefunct biotechnology company in Emeryville, California. Promega responded to the suit by claiming that the patent had been fraudulently obtained and should be invalidated.

In 1999, the US district court in San Francisco finally agreed with Promega. In his decision, Judge Vaughn Walker ruled that the original patent application from Cetus contained eight instances of misrepresentation that were intended to deceive the patent office, rendering the Taq patent unenforceable.

Roche quickly appealed. In March 2003, the US Court of Appeals for the Federal Circuit in Washington DC, overruled Walker on six of the eight cases. The appeals court then sent the case back to Walker to decide whether the remaining two instances were sufficient to justify voiding the patent. A decision is expected early next year.

One reason that the whistleblower act hardly ever comes up in patent cases is that the government rarely spends a lot of money on patented products, Aharonian says. But over the years, government agencies have spent a small fortune on Taq, including royalty payments to Roche.

Promega reached the sum of $\$ 1$ billion by claiming triple damages, as allowed by the law, plus a $\$ 10,000$ charge for each time a Taq purchase generated royalties for Roche. "This looks like a chance to go for big bucks," says Jerry Selinger, a Dallas patent lawyer and board member of the American Intellectual Property Law Association.

But Selinger and others don't give the suit much chance of success. For one thing, the Department of Justice, after reviewing the lawsuit's claims, declined to participate in prosecuting it. And although the future of Roche's Taq patent is uncertain in the United States, the European Patent Office issued a final ruling upholding it on 30 October. 